\title{
Gunboat Diplomacy: Turkey, USA and the Advent of the Cold War
}

This article aims to re-evaluate the visit of the battleship USS Missouri to Turkey on 5-6 April 1946, to ascertain whether or not it might be considered an early attempt on the part of the United States to challenge the Soviet Union. Greater historical clarity than previously possible can be afforded by the authors through the use of hitherto unreleased documents from the archives of the Ministry of Foreign Affairs of the Turkish Republic. Moreover, this article aims to achieve a more balanced and comprehensive analysis by integrating the systemic factors with the actions of crucial actors at the individual level based on new archival evidence. By doing this, our main argument emerges whereby the United States displayed its power against the Soviets via the visit of the USS Missouri only in hindsight; while the decision to send the exhumed body of the late Turkish ambassador Mehmet Münir Ertegün home, was the action of an individual. However, due to the advent of the Cold War, the dynamics shaping Turkey's search for security and ultimately the containment policy of the United States, has loaded the event with more meaning than it was originally intended, turning a 'diplomatic courtesy' into 'gunboat diplomacy.'

On his last night in Cairo, and utterly exhausted from the intense negotiations of the preceding days at the conference, Franklin Roosevelt lay down on his bed and allowed himself to become immersed in a detective novel he had been reading for some days. He had finally made it to the most gripping part of the book where the protagonist, an honorable man, was reduced to working with the flimsiest shreds of evidence and seemingly against all odds, to attain his desired goal. Despite the lure of the more obvious clues which would tie the case up so neatly, there remained one barely visible undercurrent of opinion, one route however difficult, which could yet enable the man of justice to resolve the case correctly and justly. Perhaps as Roosevelt lay on his bed, he drew parallels with his own predicament - the elusive quest for long-term stability and world peace in this, the most complex of political contexts. How, for example, was he ever going to convince Stalin that the United States and Great Britain were not hatching a plan to form a block against the Soviet Union when the great united struggle against Nazi Germany was finished? He may, he felt satisfied, have allayed these fears and suspicions in the short term here in Cairo, but would the notion and the trust be sustainable in the difficult months and years to come. A post-war world, he knew, caught between Great 
Britain and the United States in the west, and the Soviet Union in the east, could only lead to catastrophic results. ${ }^{1}$

When Roosevelt left the Cairo Conference in December 1943 these were the thoughts which preoccupied his mind. Almost a year later, and three months before his death, he used the occasion of his fourth Presidential Speech to drive the point home one final time. Quoting Emerson he underscored with characteristic simplicity the way future relations with the Soviet Union would have to be played out, saying 'The only way to make a friend, is to be a friend.' Roosevelt's worst fears, however, didn't take long to materialize after his death.

The war ended with a geopolitical vacuum at the heart of Europe, the balance of power had been destroyed, and a comprehensive peace treaty which could have reestablished it remained elusive. Moving ever closer towards a division into two rival ideological camps, Henry Kissinger remarked that the nightmare scenario that had worried Roosevelt so much resulted in a "postwar period [which] would turn into an extended and painful struggle to achieve the settlement which had eluded the leaders before the war ended. ${ }^{2}$ As a result of this the new president, Harry Truman, opted to sustain the alliance though for entirely different reasons than those which had motivated Roosevelt, and so history remembers him as the President who started the Cold War, rather than the statesman who ended the Second World War. ${ }^{3}$

Within all of this, and dwarfed by the other momentous events of 1946, was the visit of the battleship USS Missouri to Turkey on 5-6 April 1946 in order to bring the exhumed body of the late Turkish ambassador Mehmet Münir Ertegün home. The ultimate choice of the battleship itself was poignant: where the Japanese officials had signed the papers of unconditional surrender at the end of World War II. The timing of 
the trip was significant too, coinciding with the negotiations regarding the Soviet withdrawal from Iran.

For the purpose of this article, let us tighten the aperture of the Cold War to focus clearly on this event, its ramifications and implications. Perhaps it is merely a footnote in global history, but it is a significant one for the region and for the strategic positioning of Turkey in the post-war world. Actions, it is said, speak louder than words and so the aim of this study is to re-evaluate the event and ascertain whether or not it might be considered an early attempt on the part of the United States to challenge the Soviet Union. Greater historical clarity than previously possible can be afforded by the authors through the use of hitherto unreleased documents, recently made available to researchers at the Ministry of Foreign Affairs of the Turkish Republic.

We also wish to pursue a second strand of interpretation brought to light in these hitherto unseen documents: the role of the individual. To contextualize these comments, James N. Rosenau's identification of levels of global political analysis is particularly useful. James N. Rosenau identifies six levels of analysis in world politics: (1) world system; (2) relations; (3) society; (4) government; (5) role; and (6) individual. ${ }^{4}$ In the events pertaining to the Cold War era, traditionally world system based explanations are predominant and all other levels which might have a significant impact are often neglected. In a similar fashion, while there have been several systemic based interpretations of the USS Missouri visit to Istanbul strictly defined by the newly emerging dynamics of the Cold War era, particularly the individual level of analysis is downplayed, or omitted. Thus, this article aims to achieve a more balanced and comprehensive analysis by integrating the systemic factors with the actions of crucial 
actors at the individual level based on new archival evidence. By doing this, our main argument emerges whereby the United States displayed its power against the Soviets via the visit of the USS Missouri only in hindsight; while the decision to send the exhumed body of the late Turkish ambassador Mehmet Münir Ertegün home, was the action of an individual. The timing of the event, the eventual choice of the battleship, the parameters shaping Turkey's search for security, and ultimately the containment policy of the United States, has loaded the event with more meaning than it was originally intended, turning 'a diplomatic courtesy' into 'gunboat diplomacy.'

\section{I.}

Alexander Wilbourne Weddel had resigned from the State Department after serving a final tumultuous term in Franco's Spain. For four blissful years now he and his wife had been enjoying his retirement in Richmond, Virginia, allowing themselves the luxury of time to garden, to pursue hobbies such as the Virginia History Club (of which he became president), and other worthwhile causes and socially responsible projects. ${ }^{5}$ In February 1946, however, an unexpected phone call shattered the domestic idyll and called the Weddels back into the service of the nation one more time. The task: to deliver the recently exhumed body of the late Turkish Ambassador Mehmet Münir Ertegün's (who had died in 1944), personally to the president of Turkish Republic, İsmet İnönü, as the special representative of President Truman. Weddel, who had been a close personal friend of Franklin Roosevelt, accepted this diplomatic mission without a second thought, and so started preparing, with his wife, for their trans-Atlantic journey on board the iconic battleship USS Missouri. Simultaneously, and significantly, Winston Churchill was 
drafting his historic 'iron curtain' speech in which he was determined to warn the US government and public, who still thought that they could negotiate with Stalin, of the imminent and very real dangers of Communism. ${ }^{6}$ In his speech, delivered in Fulton, Missouri, Churchill highlighted the Soviet threat against Turkey in particular - and this only a matter of days before the Weddels' arrival.

A year before all of this, on March 19th 1945, the Soviets delivered a note to the Turkish Ambassador in Moscow, Selim Sarper, in which it was made clear that the Soviet-Turkish Friendship and Non-Aggression Pact would end in November of the same year. The Soviet Minister of Foreign Affairs, Molotov, also stated that the Soviet Union would not renew the agreement, but would be willing to reach some other compromise more relevant to the post-war climate. On April $4^{\text {th }} 1945$, the Turkish Minister of Foreign Affairs, Hasan Saka, responded to Moscow by acknowledging that the possibility of a new treaty/agreement seemed mutually desirable. When negotiations began however, Selim Sarper faced seemingly new Soviet demands from Molotov. Later, Sarper described the first few minutes of this stressful meeting to his clerk, İlhan Akant, and it is worth reproducing here in full:

As soon as I entered the room, I noticed that Molotov was not standing up. So, I started walking slowly from the door to his table. As I approached the table Molotov finally stood up. He shook my hand over the table. Then, he showed me the sofa right across from him. He sat by his desk. This was the kind of greeting that was traditionally made to the satellite states of the Soviet Union. There were two translators standing next to Molotov's desk. I realized that Molotov wanted to treat me in a commanding manner. The reason for this assumption was the fact that he stood up as soon as I entered the room in our previous meetings. Moreover, in our previous meetings, the discussion did not take place by his desk, but it took place sitting at sofas placed right across from each other.

The commanding nature of Molotov's greeting, Sarper concluded, set the tone for a tense meeting to follow. He went on: 
In our previous meetings, he used to ask how I was doing, while offering me Russian tobacco and papyrus. And I would offer him Turkish cigarettes from the cigarette case that I carried in my pocket. I did not pull out my cigarette case, until Molotov offered me a cigarette. At last, Molotov offered me the cigarette without asking me how I was and I took the cigarette he offered me really slowly, pulling out my cigarette case and offering him Turkish cigarettes at the same time. I waited for Molotov to light my cigarette with his lighter. As he approached to light my cigarette, I pulled out my own lighter and we lit each other's cigarettes. I wanted to undermine his commanding manner by acting slowly. ${ }^{7}$

This was only the prelude. Now the sparring started in earnest with Molotov presenting Sarper with the new Soviet demands which included: a revision of the national borders yielding Kars and Ardahan to the Soviets, a change in the status of the Straits, and a demand for a Soviet base in this area. Ambassador Sarper refused these demands then reported the meeting back to Ankara, which in time informed the Soviet Union that while the Montreux Treaty might yet be discussed, it could only be done so on a multilateral platform. At the same time Turkey, while deliberately stalling on Soviet demands, initiated a period of intense diplomatic traffic to muster the support of the UK and the US. The Turkish Undersecretary of State, Feridun Cemal Erkin, would later name this diplomatic jousting, the 'Turkish-Russian Duel.'8

Towards the end of 1945, it was becoming clear that the Foreign Ministers of the leading powers were failing to reach a consensus regarding the post war world. Potsdam, and other conferences, was displaying ever growing levels of mistrust among the erstwhile allies. Stalin was suspicious of the UK-US alliance (as he hadn't been informed in advance about the atomic bomb dropped on Hiroshima), while concomitantly, the United States was growing apprehensive about Stalin's expansionist attitudes in Eastern Europe and Iran. ${ }^{9}$ In Washington the Ministry of Defense and the State Department were at loggerheads as to how to react. The Secretary of the US Navy, James Vincent Forrestal, wanted to dispatch an American naval force to the 
Mediterranean, but the Secretary of State James F.Byrnes, did not want to provoke the Soviet Union unless it was absolutely necessary, and so rejected this suggestion. ${ }^{10}$ The State Department did however acknowledge the fact that Washington should no longer hold itself responsible for the irreconcilable attitude of the Soviet Union and instead advocated the development of new strategies against Soviet expansionism. ${ }^{11}$ This report was kept confidential in accordance with Truman's direct orders, but it was clear to both civilian and military bureaucracy that the superpowers had entered a new era and that they were now in uncharted waters.

II.

In the early hours of a late 1945 morning Turkish Ambassador Hüseyin Ragip Baydur left the US State Department and walked pensively back to the Turkish Embassy's Chancellery. His was a painful duty for his highly-respected predecessor. A few weeks earlier, he had heard that the late British Ambassador Phillip Kerr's ${ }^{12}$ ashes were to be repatriated and, inspired; he had contacted Ankara to permit the same honor for his late friend Mehmet Münir Ertegün. Ertegün had died in November 1944 and had rested temporarily in Arlington cemetery ever since. Now Baydur wanted to ask for Ertegün's remains to be returned to his homeland, a request which Ankara fully endorsed. ${ }^{13}$ In the subsequent meeting with US authorities, he was similarly assured that his predecessor would be sent back to Turkey in a way that would befit the late Ambassador's high-esteem. Indeed Münir Ertegün's family has already requested the same privilege right after the ambassador's death, but at that time the US authorities had informed the grieving family that under the circumstances the project would be both risky 
and stripped bare of the dignity and decorum that was rightfully his. To return in a cargo ship, which was an option, seemed inappropriate to all concerned. ${ }^{14}$ Waiting for peace, then doing the job right, seemed preferable even to Münir Ertegün's reluctant widow. ${ }^{15}$

On January 25, 1946, Dean Acheson had proposed that the late ambassador's remains be returned aboard a cruiser as a courtesy in line with diplomatic practice and Truman accepted this suggestion. However, because of a shortage of cruisers in the Atlantic, ultimately the Missouri was designated to return the body. ${ }^{16}$

The visit of the USS Missouri to Turkey, with all its implications and myriad messages, was announced to the American public on March $6^{\text {th }} 1946$ - the day after Churchill had delivered his iron curtain speech in the United States. The US and Turkish governments, however, warned the press not to read too much into the event and told them instead that this was merely ceremonial, an honor to a long standing friend of their countries. ${ }^{17}$ For many others, it was clear that Truman was still trying to identify, and then refine, a strategy with which to deal with Stalin. ${ }^{18}$

In the meantime, in line with Secretary of the Navy Forrestal's earlier ideas of sea power and global strategy, he suggested to Secretary of State Brynes that a task force could be sent to the Mediterranean accompanying the Missouri. Initially, Brynes viewed this proposal favorably and both men thought that such a gesture of power would provide encouragement to Turkey and Greece. ${ }^{19}$ However, because of the demand for naval forces in the Far East, the dynamics of rapid demobilization, and perhaps a change of view on Brynes' part as the Iranian crisis unfolded, the Missouri would depart for Turkey without the accompanying task force. ${ }^{20}$ When Forrestal informed Churchill on 10 March that the task force would not accompany 
the Missouri, he was quite disappointed. He told Forrestal that "a gesture of power not fully implemented was almost less effective than no gesture at all" and to make the gesture effective the entire task force should sail into the Sea of Marmara."21 However, in compliance with an earlier Joint Strategic Survey Report approved by the Joint Chiefs of Staff, which recommended that the United States should avoid military commitment to American interests in the Near East other than through the United Nations, ${ }^{22}$ the Americans were reluctant to make such a grand gesture of power as suggested by Churchill at this stage. Nevertheless, the symbolic character of the Missouri visit was still significant.

On March 21th 1946, Ertegün's remains were exhumed from their resting place in Arlington cemetery, delivered to New York, and there placed on the imposing USS Missouri. His widow, Hayrunüssa, and their children, were accompanied to the port simultaneously by Truman's special representative Ambassador Weddel and his wife, the master of ceremonies Kadri Rizan, the Undersecretary of the Embassy Mennan Teleben, and Ambassador Baydur. ${ }^{23}$ As she could not accompany her husband's body on its homeward journey to its final resting place in the Özbek dervish lodge in Istanbul, she made her tearful farewell at the harbor.

The dispatch of the battleship USS Missouri to Istanbul has been interpreted as a vivid symbol of the growing American support for Turkey in an increasingly hostile environment. $^{24}$ In his Army Day speech on April 6, 1946, Truman stated that the sovereignty of the countries in the Middle East must not be threatened by coercion and that the United States also had responsibility in preserving the peace in this region. ${ }^{25}$ Thus, this incident of 'diplomatic courtesy' was turning into a strategic instance of 
'gunboat diplomacy,' whereby the American leaders were sending a signal to the Soviet Union, as well as to Turkey, of their growing interest in, and long-term commitment to, the Middle East and of their new tougher stance towards Soviet expansionism.

As anticipated when the USS Missouri docked in Istanbul on April $5^{\text {th }} 1946$, it was greeted with the all pomp and circumstance, ceremonies and public manifestations, anticipated from the outset. ${ }^{26}$ The press covered every conceivable detail of the visit while a famous poet of the time even captured in verse the events of that day. ${ }^{27}$ Even the Leanders Tower (Kız Kulesi) was draped with a "Welcome Missouri” sign. Moreover, the Turkish tobacco monopoly (Tekel) produced 30,000 packages of commemoratory cigarettes, named "Missouri," to be distributed as gifts among the American visitors. ${ }^{28}$ The visit immediately resonated among the Turkish public as well. Ahmet Emin Yalman in his editorial in Vatan, titled "Why were we ecstatic?" described the mood upon the arrival of the American visitors, saying "All of the people in Istanbul and Turkey are talking about the Missouri and the two American destroyers accompanying it. People are creating legends about the heroic deeds associated with the Missouri and the rumors are rapidly spreading." 29

Yalman pointed out that the underlying reason for this attitude was not simply an expression of Turkish gratitude for the American gesture regarding the late Turkish diplomat, but also the public perception that this visit was "a strong indicator of the humane guarantee in response to their need for peace and security." ${ }^{30}$ In short, the Missouri's visit was seen as a sign of the American support in response to an emergent Soviet threat. Three caricatures published in Cumhuriyet, were quite significant in reflecting the Turkish mood regarding the visit of the Missouri. In the first caricature, 
titled "It's Coming," all the European and the Middle Eastern powers, as well as a frustrated Russian soldier, were closely watching the journey of the battleship Missouri across the Mediterranean towards a welcoming Turkish soldier. ${ }^{31}$ The second caricature depicted the firing of the canons of the Turkish and the American navy in greeting, or maybe as a warning shot, to thwart the plans of their enemies. Finally, in the third one, titled "It's Leaving," the Missouri was leaving, packed to the gunwales with hearts. ${ }^{32}$

Following the actual funeral in Istanbul, the captain of the battleship (Admiral Hewitt), the special representative of the president (Weddell), and a group of journalists accompanying them, traveled to Ankara to make a formal visit to the President, the Prime Minister and the Chief of General Staff. In a speech delivered to the press, Weddell acknowledged that he was here to deliver a very personal message from President Truman to İsmet İnönü, but that he could not reveal its precise contents. Weddell found it sufficient to say though that, in essence, 'Truman is requesting İönü and the Turkish Republic to be a closer friend of the United States. ${ }^{33}$ Similarly, Admiral Hewitt told the press that the United States government wanted Turkey to be prosperous and strong. Giving evasive answers to the questions regarding the political significance of the visit, Admiral Hewitt stated that "the underlying reason for the Missouri's visit to Turkey is to symbolize the friendship among the two countries and to make gesture of international courtesy." ${ }^{34}$ Although the high level American visitors refrained from openly confirming that their mission was more than a courtesy call, to the man on the street it still presented a tangible proof that Turkey did not stand alone.

The Ankara government also used the occasion to stress Turkey's solidarity with the United States. The visitors were enthusiastically received by Prime Minister Şükrü 
Saraçoğlu and President İnönü. In his speech, the Turkish Prime Minister praised the American people and ideals by stating "The Americans, who are the youngest and most esteemed child of this old world that we live on, are taking firm and undaunted steps in the path of creating a peaceful international order and a united world by upholding the flags of humanity, justice, freedom, and civilization." ${ }^{, 35}$ While Saraçoğlu's speech focused mainly on the ideals, İnönü took the opportunity to address the more tangible and pragmatic aspirations concerning the Turkish desire to obtain a $\$ 500$ million credit from the Export- Import bank. ${ }^{36}$ Moreover, the President voiced the desirability of having American ships in the Mediterranean as an insurance for peace and stated unambiguously "the closer the ships of the American navy to us, the better it is.",37

As the 'Welcome Missouri' banners and headlines receded over the horizon, and with the US sailors salute of 'long Live Turkey' still ringing in the ears of those who witnessed her weighing anchor, the great vessel now sailed for Greece on April $9^{\text {th }}$. Might this have been a foreshadowing of the Truman Doctrine that would be declared a year later? When the Athens correspondent of Vatan, Faruk Fenik, asked the sailors who had recently arrived from Istanbul two days later 'How is the weather in Istanbul?' to which he got the following light-hearted, but loaded, response: 'When we first came it was a bit cloudy. There were cold winds coming from Russia. But then everything got better. Now the weather in Istanbul is perfect, like in the rest of Turkey.'

Behind the jovial veneer, however, serious complications were beginning to resurface. The Soviet Union would soon deliver two very threatening notes to Turkey in August and September, 1946 regarding the Straits. On August 7, 1946, Moscow's reiteration of its demands for the shared control of the waterway was also accompanied 
by naval activity in the Black Sea and troop movements in the Caucasus. ${ }^{38}$ In response to this threatening Soviet move, the Turkish leaders urgently sought the support of the United States and Britain by indicating their desire for a coordinated response.

Given the seriousness and complexity of the situation, in Washington the Departments of State, War, and Navy all worked on the problem. Finally, on 15 August, they prepared a joint memorandum for the President on Turkey and the Soviet Union. ${ }^{39}$ The memorandum acknowledged that the Soviet Union's objective was to establish their control over Turkey. The report claimed that if the Soviet's managed to enforce a joint control of the Straits, it would be extremely difficult for the United States to prevent Moscow from obtaining control of the entire Near and the Middle East. Thus, the memorandum concluded that it was in the vital interest of the United States that the Soviets should not succeed either by force or through the threat of using force in imposing their unilateral plan with respect to the Straits and Turkey. It highlighted that only if there is a clear understanding of a firm American determination to support Turkey, the Soviets would be deterred. ${ }^{40}$ When Dean Acheson presented this memorandum to the president, he also argued that Moscow's 'trial balloon' should be strongly resisted. After a lengthy discussion and pondering a map on Truman's desk, the President also concurred that Washington should take a firm position. ${ }^{41}$

Hence, the efforts of the Turkish officials paid off on August 19, 1946, when the United States replied to the Soviets with a note firmly backing the Turkish stand. The American note emphasized Turkey's right to maintain full control over the Straits, while rejecting the idea of a Straits regime administered by the Black Sea powers alone. This time the United States also indicated its toughening stance by stating that attacks or 
threats of attack against the Straits would be considered as matters for action by the United Nations Security Council. ${ }^{42}$ Moreover, corresponding to the Soviet moves, the United States increased its naval activities in the Mediterranean and American and British warships took part in joint maneuvers in the Aegean during September 1946.

When the frustrated Kremlin sent another note on September 24, 1946, repeating much of its earlier demands with an additional emphasis on the Black Sea as a mare clausum, it was once again confronted with a coordinated response from Turkey, the United States, and Britain. Although they reiterated their willingness to participate in a conference to update the Montreux Convention, all three rejected the major Soviet demands outright. ${ }^{43}$ Consequently, realizing that they lacked the necessary support to achieve their goals diplomatically, the Soviets sent a message to London (instead of a direct reply) declaring it premature to call for such a conference.

In response to the Soviet notes, and their timbre, Turkey began to accelerate its efforts to gain more concrete US support against what was now rapidly becoming a Soviet threat. ${ }^{44}$ In the meantime, the United States was starting to shape and implement its containment policy in which Turkey would play a significant future role. This subsequent period from 1946 to 1952, would not only mark the origins of the Cold War and the emergence of a bipolar world, but it would also observe the Turkish scramble for security within a more sustainable and institutional framework, which would ultimately result in Turkey's full NATO membership.

III. 
An ever-present challenge in the writing of diplomatic history is attaining access to the archival documents which have always been kept under lock and key. Even if the researcher does manage to access them, while evaluating the documents in hand $\mathrm{s} / \mathrm{he}$ is constantly asking him/herself 'I wonder which ones are still kept confidential?' Thus, we must assume, the history of diplomacy is reconstructed and written using an incomplete set of building blocks. What made this research possible was the granting of special permission to access the documents concerning the visit of the USS Missouri, and documents relating to Turkish-US relations in 1944-1947 in the archives of the Turkish Ministry of Foreign Affairs, which remains closed to public in general. ${ }^{45}$ This article, therefore, based as it is on a set of hitherto unused official documents, also acts as a pointer of what might yet be achieved by historians when the archives are finally made public.

Given the lack of access to archival documents of the Turkish Foreign Ministry, the number and diversity of different assessments and interpretations of this event, nationally and internationally, are remarkable. ${ }^{46}$ To cite but a few: Haluk Gerger interpreted the event as baiting Turkey and as a provocation instigated by the Untied States. ${ }^{47}$ Lewis Thomas and Richard Frye stated that the visit opened a new chapter in world politics. ${ }^{48}$ Theodore Couloumbis evaluated the incident as muscle-flexing against the Soviet Union, ${ }^{49}$ while Walter Lafebar argued that the visit was a harsh response to the Soviet Union's attitude of expansionism. ${ }^{50}$ All overlook the importance of the individual and it is to that we now wish to draw attention.

Another major challenge in the writing of diplomatic history is that 'the human factor' is rarely adequately reflected or acknowledged. The roots of this problem lie 
within the scope of the classical definition of diplomacy and the way this definition is perceived. Diplomacy is defined as the direct delivery of a government's thoughts and opinions concerning a matter to other states' decision makers. Thus, in the writing of diplomatic history the message and the method of its delivery are usually seen as one and the same. Individual diplomats are often viewed as government representatives and mere spokesmen of government policies. This is certainly the case in the literature pertaining to Turkish diplomatic history, where there is normally only reference to governments and government policies, making the diplomats who represent, and implement, them invisible. The authors of this article would suggest strongly, on the other hand, that international political dynamics can often only be realized through initiatives by prominent individuals.

Our opinion is that the US government did not send the USS Missouri in 1946 to threaten the Soviet Union. It also did not view the delivery of the body of the late ambassador to Turkey as a means of gaining the support of the Turkish government against the Soviet Union. The raison d'être was simpler than that: the British Ambassador Philip Kerr's ashes had recently been delivered to his homeland, and in keeping with this, Hüseyin Ragip Baydur proposed the same honor for his predecessor. It was therefore merely a diplomatic honor afforded to significant personages at the behest of an individual- nothing more. However, once the decision was made, its symbolic significance within the emerging Cold War dynamics came to the forefront.

Of course we are left with a list of 'what ifs.' Had Hayrunissa Ertegün insisted on her husband's body being delivered in a cargo ship in 1944, would the USS Missouri have visited Turkey under a different guise in 1946? At the same time, if the British 
Embassy had not asked for the delivery of Philip Kerr's ashes, would Ambassador Baydur have started a proposal for the delivery of his late successor? It is hard to say. Kerr's ashes were sent quietly to his homeland, arriving on December $11^{\text {th }} 1945$ on board the ship on which the Atlantic Treaty had been signed. British politicians did not view the visit of this prestigious ship as a diplomatic victory, or read into it any symbolic gesture of their continuing solidarity with US. Subsequent historians have not placed too much emphasis on the idea of saber rattling or strategic movement of pawns across a chessboard either. But, whatever the reason, the visit of the USS Missouri to Turkey is viewed entirely differently and has taken its place in the literature of the era as one of the opening gambits of the Cold War. ${ }^{51}$ Accounts in Turkey and the US have rarely differed. Perhaps it was Niyazi Berkes who came closest in his assessment of the event and the intensions of Truman, when he wrote:

The US president of the time, Truman, wasn't the Truman of the later times...It wasn't a visit trying to show Truman's beloved doctrine of the times 'the absolute independence of the straits and their demilitarization'. The Soviet Union was as much opposed to this idea as was Turkey. But after one year, in March 1947 as he declared his famous Truman doctrine, he was facing the world as a President that has revisited and radically changed his old worldview. ${ }^{52}$

In conclusion, in April 1946, the visit of the USS Missouri battleship to Istanbul has been interpreted as a manifestation of the US government's decision to support Turkey against the Soviet Union. However, while there was definitely a wish to display power against the Soviets during the Missouri's visit, this was not a display of power aiming to declare that the US would be clearly supporting Turkey yet. This incident, which started out as a 'diplomatic courtesy,' turned into and has been interpreted as 'gunboat diplomacy' as the winds of change were rapidly blowing throughout Turkey and 
the post-war world, establishing a bipolar order of rivalry, distrust and covert strategy which would come to characterize the Cold War.

The authors gratefully acknowledge the contributions of Michael Walsh. Suhnaz Yilmaz would like to thank TUBA for its financial support thorugh the GEBIP and TÜBITTAK for its support thorugh the BİDEB Program. She would also like to thank CREEES at Stanford University.

${ }^{1}$ E. Roosevelt, İf̧sa Ediyorum ( İstanbul: Nebioğlu Yayınevi ) p. 153.

${ }^{2}$ H. Kissinger, Diplomacy, ( New York: Simon \&Schuster,1994), p.422.

${ }^{3}$ Ibid, pp. 423-445.

${ }^{4}$ J. Rosenau, The Scientific Study of Foreign Policy, (rev.ed. ,London: Frances Pinter, 1980), chap.6.

${ }^{5}$ www.vahistorical.org/vh/weddels_aw.htm

${ }^{6}$ Origins of Cold War, Edit. Thomas G. Paterson, (Massachusetts :D.C. Heath and Company, 1974), pp.1117.

${ }^{7}$ I. Akant, Moskova Otel National 333 Numaralı Oda,( Istanbul: Milliyet Yayınları, 1990), pp.113-114.

${ }^{8}$ F. C. Erkin, Türk- Sovyet İlişkileri ve Boğazlar Meselesi,( Ankara,T.T.K Yayinlari, 1968), p. 255.

${ }^{9}$ H. Kissenger, Diplomacy, p. 411

${ }^{10}$ H. Ülman, Türk-Amerikan Diplomatik Münasebetleri 1939-1947, (Ankara: Siyasal Bilgiler Fakültesi Yayınları, 1961), p.74.

${ }^{11}$ Origins of Cold War, p.23, W. D. Miscamble, George F. Kennan and the Making of American Foreign Policy, 1947-1950, (New Jersey: Princeton University Press, 1992), pp. 3-5.

${ }^{12}$ www.questia.com/googlescholar/ Philip Kerr.

${ }^{13}$ Turkish Republic, Archive of Ministry of Foreign Affairs ( Hereafter AMFA), No: 492/53.

${ }^{14}$ Personal Interview with Ahmet Ertegün, Mica-Ertegun Conference, Princeton University, April, 2003.

${ }^{15}$ AMFA No: $5147 / 363$

${ }^{16}$ B. R. Kuhniholm, Origins of the Cold War in the Near East: Great Power Conflict and Diplomacy in Iran, Turkey, and Greece, (Princeton University Press, 1980), p. 336.

${ }^{17}$ AMFA No: $923 / 104$

18 Foreign Relations of United States, Diplomatic Papers, 1946, Vol VI. Eastern Europe, The Soviet Union, p. 864, (Hereafter FRUS) AMFA No: 1128/ 117.

${ }^{19}$ R. Albion and R. Connery, Forrestal and the Navy (New York: 1962), pp. 186-187; J. F. Byrnes, All in One Lifetime, (New York, 1958), p.351 .

${ }^{20}$ B. R. Kuhniholm, Origins of the Cold War in the Near East, p. 336.

${ }^{21}$ W. Millis, ed. The Forrestal Diaries, (New York, 1951), pp.144-146.

${ }^{22} 10$ February 1946 Report by Joint Strategic Survey Committee, United States Army, Operations Division, Modern Military Records Branch, National Archives, Washington D.C., CCS 092, United States 12-21-45; B. R. Kuhniholm, Origins of the Cold War in the Near East, p.336.

${ }^{23}$ Personal Interview with Ahmet Ertegün, Mica-Ertegun Conference, Princeton University, April, 2003; AMFA Document No. 1128/ 117.

${ }^{24}$ On the illness and the death of Ertegün, see Mehmet Münir Ertegün, $A M F A$, No.63; AMFA, No. 301, AMFA, No. 360 .

${ }^{25}$ U. S. Department of State, Bulletin, April 14,1946, p. 622; Bilal Şimşir, Bizim Diplomatlar (Ankara, 1996), p. 317.

${ }^{26}$ İ. Bozkurt, 'İkinci Dünya Savaşi Sonrası Amerikan Missouri Zırhlısı'nın İstanbul Limanını Ziyareti

Üzerine Değerlendirmeler', ÇTTAD,VI/15 (2007/Güz), pp.251-274.

${ }^{27}$ Vatan, April 13, 1946.

${ }^{28}$ Vatan, April 5, 1946.

${ }^{29}$ Vatan, April 8, 1946.

${ }^{30}$ Ibid.

${ }^{31}$ Cumhuriyet, April 4, 1946.

${ }^{32}$ Cumhuriyet April 8, 1946. 
${ }^{33}$ Vatan, April 6, 1946

${ }^{34}$ Vatan, April 6, 1946.

${ }^{35}$ Vatan, April 7, 1946; NYT, April 7, 1946.

${ }^{36}$ Since the Turkish request for a credit of $\$ 500$ million from the Export-Import Bank exceeded the total resources available to that lending agency, the Turkish officials were informed that Turkey would receive a maximum of $\$ 25$ million. FRUS, 1946, vol.7, pp. 902-903.

${ }^{37}$ Ibid.

${ }^{38}$ For the text of the Soviet note, see U. S. Department of State, The Problem of the Turkish Straits [ hereafter Straits] (Washington: 1947), pp. 47-49.

${ }^{39}$ FRUS, 1946, VII: 836-838.

${ }^{40}$ Ibid.

${ }^{41}$ D. Acheson, Present at the Creation, (New York, 1969), pp. 195-196.

${ }^{42}$ For the text of the U.S. note, see Straits, pp. 49-50; FRUS, 1946, vol.7, pp. 840-842.

${ }^{43}$ For the texts of the Soviet note of September 24, 1946, the American and the British notes of October 9 , 1946 and the Turkish note of October 18, 1946, see Straits, pp. 55-68.

${ }^{44}$ A. Sever, Soğuk Savaş Kuşatmasında Türkiye, Batı ve Ortadoğu 1945-1958,(İstanbul: Boyut Yayınları, 1997) , pp. 36-43.

${ }^{45}$ Arşivler ve Arşiv Belgeleri, Türk Dış Politikası Çalışmaları, Cumhuriyet Dönemi İçin Ulusal Rehber, edit. Engin Berber, (Istanbul: Bilgi Üniversitesi Yayınları, 2007), pp. 25-32

46 M. Toker, Türkiye Üzerinde 1945 Kabusu,( Ankara:Akis Yayınları, 1971); Türkiye Dış Politikasında 50.Yıl, İkinci Dünya Savaşı Yılları,( Ankara: Türkiye Cumhuriyeti Dışişleri Bakanlığı Araştırma ve Siyaset Planlama Genel Müdürlüğü, 1973), Olaylarla Türk Dış Politikası 1919-1980, (Ankara: Siyasal Kitabevi, 1993).

${ }^{47}$ H. Gerger, Türk Dış Politikasının Ekonomi Politiği, (Istanbul:Belge Yayınları,) p. 48.

${ }^{48}$ L. V. Thomas ve R. N. Frye, The United States, Turkey and Iran, (Cambridge: Archon Books, 1971), p. 100.

${ }^{49}$ T. A. Couloumbis, The United States, Greece and Turkey, Troubled Triangle, (New York:Praeger Special Studies, 1983), p. 12.

${ }^{50}$ W. Lafeber, America, Russia and Cold War 1945-1947, (Canada: Third Edition, John Milley and Sons Inc., 1976), p. 37.

${ }^{51}$ FRUS, 1946, Vol VII, The Near East and Africa, pp. 822-823.

${ }^{52}$ Niyazi Berkes, Unutulan Yıllar, ( İstanbul: İletişim Yayınları 1997), pp.377-378, cited in İ. Bozkurt, 'İkinci Dünya Savaşi Sonrası Amerikan Missouri Zırhlısı'nın İstanbul Limanını Ziyareti Üzerine Değerlendirmeler', p.266. 